All paper-testing work, on strength and printing quality, is carried out in this laboratory, where is also installed a small printing machine on which printing tests can be carried out under controlled conditions.

GEneral offices and library are housed on the ground floor of the Laboratories. From the library, the Intelligence Section of the Association's work is operated and the "Review of Literature" published. The physics department is contained on the first floor where work on colour fading, examination of adhesives and bookbinding materials are carried out. This department also contains a section for photomicrographic work on paper fibres, inks, prints and printing alloys, and a dark room for ultra-violet and infra-red work. The upper floor has been converted into two chemical laboratories. One is mainly for analytical work in connexion with the day-to-day problems submitted by member firms, and the other set aside as a chemical research laboratory for dealing with the longer-ranged problems connected with the working properties and drying of printing inks, lithography, photogravure printing, stereotyping and electrotyping, etc. It is the aim of the Research Association to deal with both the day-to-day problems and the longer-ranged work connected with printing processes and raw materials, and to build up a scientific background to one of the 'craft' industries so that the inherent difficulties, now aggravated by increased speeds of production, can be eradicated and the future developments of the industry guided by scientific research.

\section{The West Indian Volcanoes}

Ат the Friday evening discourse delivered at the Royal Institution on March 12, Sir Gerald P. LenoxConyngham described "Montserrat and the West Indian Volcanoes". The island of Montserrat has recently suffered from a series of earthquakes. They began about the beginning of 1934 and continued with varying intensity all through 1934 and 1935. In the autumn of 1935 the inhabitants sent a petition to the Governor praying that steps should be taken to discover, if possible, whether there was danger of an eruption. Their anxiety was due to their recollection of the events of 1902 when eruptions of the Soufrière of St. Vincent and of Mont Pele of Martinique did terrible damage. Such an eruption in Montserrat would be most dangerous to the town of Plymouth. As a result of the petition, a small expedition consisting of a geologist and a physicist was sent out. Frequent severe shocks were felt up to November 1935. After that date the activity of the volcano became steadily less. A good measure of success was attained in locating the positions of the foci, and it is now known that they were all situated in a belt about four miles wide which crosses the island from south-west to north-east. The West Indian island arc bears strong resemblance to the East Indian are that runs eastwards from Java. In 1929-30 Dr. Vening Meinesz of the Dutch Geodetic Commission made a gravity survey of the seas around these islands and found that there is a belt of negative gravity anomaly lying outside the island arc. The circular form of island and mountain ares is suggestive. It is probable that the form is determined by the intersection of a thrust plane with the sphere. $\mathrm{Mr}$. $P$. Lake has pointed out that the radius of the arc gives the dip of the fault where the thrust plane cuts the surface. It is believed that gravity determinations combined with the consideration of the curvature of the island chain and of the probable position of the over-thrusting foot of the tectonic are on which the islands have been built up by voleanic agency will throw light on the structure of the region.

\section{New University Studies}

AT the recent annual meeting of the Court of Governors of the University of Birmingham, the vice-chancellor, Sir Charles Grant Robertson, noted a small decline in the number of students in the University, possibly due to the decline in the birthrate (though periods of 'boom' in trade have on previous occasions been associated with a slackening in the entry to the University). The Faculty of Medicine, however, shows no such falling off. $\mathrm{He}$ commented with satisfaction on the success of the Appointments Board and the evidence of an increasing demand for the product of the University in industry--in fact, during the past year the demand on the Appointments Board exceeded the supply. Sir Charles dealt with the lack of the study of the social sciences in English universities. It has been suggested that the education of a university graduate is incomplete without some such study, but there is the difficulty of finding the time without omitting some other part of the curriculum. It appears probable that little can be done unless there is a specialist social science degree course, or the subject is made one for a post-graduate course of at least one year; and then there is the problem of finding posts for such graduates, with adequate pay and prospects of promotion, so long as the wide field of municipal civil service is barred to university graduates. Sir Charles expressed sympathy with the Government's desire to promote physical training in universities, but, in addition to the fact that the necessary trainers do not at present exist, the thorny problem of compulsion or non-compulsion would have to be solved.

\section{The Universities and Social Science}

A SPEECH entitled "A Citizen Challenges the Universities", delivered by Sir Ernest Simon at the summer, 1936, meeting of the Council of the Association of University Teachers in Cardiff, appeared in the Universities Review of November last, and a reprint of it has reached us. The challenge relates to the imminent threat to democracy involved in our tolerance of such conditions as those of South Wales and other depressed areas, and the universities' alleged neglect, in the face of that threat, to do their duty by the social sciences: their failure alike to provide adequate inducements, staff and equipment for research in those sciences and for specialized study in them, and to employ effectual measures for ensuring that students, of whatever schools, shall 